\title{
ANALISA KELAYAKAN TARIF PADA PERUSAHAAN DAERAH AIR MINUM (PDAM) KOTA BLITAR,JAWATIMUR BERDASARKAN PENGEMBALIAN BIAYA PENUH (FULL COST RECOVERY)
}

\author{
Nurika Mauliyah \\ Dosen Fakultas Ekonomi Universitas Islam Balitar \\ Email:mauliaroksin@gmail.co
}

\begin{abstract}
ABSTRAK
Kegiatan bisnis bertujuan pada perolehan laba agar dapat digunakan sebagai sumbe runtuk menjaga kelangsungan hidup serta perkembangan perusahaan. Untuk mencapai laba yang diharapkan perusahaan hendak nyamenyiapkan perencanaan yang sebaik-baiknya tentang target volume penjualan dan harga jual (tarif) per satuan, serta rencana-rencana biayanya. Penelitian ini adalah Studi Kasus pada PDAM Kota Blitar, Khususnya tentang Analisa Break Even Point (TitikImpas), sehingga rumusan masalah yang diajukan adalah "Bagaimanakah penetapan harga jual (tarif) air minum pada Perusahaan Daerah Air Minum (PDAM) Kota Blitar agar dapat menutup seluruh biaya perusahaan?" dan dengan tujuan "untuk mendapatkan gambaran tentang penetapan harga jual (tarif) air minum pada Perusahaan Daerah Air Minum (PDAM) Kota Blitar.

Agar mendapatkan gambaran tentang perencanaan volume penjualan dan harga jual yang layak, penganalisaan dilakukan dengan menggunakan analisa Titik Impas (Break Even Point). Break Even Point atau Titik Impas merupakan suatu titik yang menunjukkan bahwa pendapatan total yang dihasilkan perusahaan sama dengan jumlah biaya yang dikeluarkan, sehingga perusahaan tidak memperoleh laba dan tidak mengalami kerugian.

Dari penganalisaan yang telah dilakukan diperoleh fakta bahwa tingkat Break Even Point terlalu tinggi, yaitu BEP (unit) per tahun $=1,982,367 \mathrm{~m}^{3}$, $\operatorname{BEP}($ Rp) pertahun $=$ Rp5,819,992,173.97,-

Jika dipertahankan seperti kondisi sekarang maka untuk dapat menutup seluruh beban usaha (Full Cost Recovery) Perusahaan Daerah Air Minum (PDAM) Kota Blitar harus mendapatkan subsidi dari Peemerintah Kota Blitar dan atau Pemerintah Provinsi Jawa Timur rata-rata per tahun sebesar Rp 3,175,050,902,-

Jika Perusahaan Daerah Air Minum (PDAM) Kota Blitar tidak berkehendak mendapatkan subsidi dari Pemerintah Daerah, dan ingin menutup seluruh beban usaha bisa menempuh kebijakan harga baru untuk masing-masing kelompok pelanggan per $m^{3}$ yaitu : Non Niaga Rp 5,824,- ; Niaga Rp 5,960,-; Sosial Rp 6,014,-; Instansi Pemerintah $R p$ 5,867,- ; Rp 5,358 dan Kran Umum Rp 6,332,-.
\end{abstract}




\section{PENDAHULUAN \\ Latar Belakang Masalah}

Kegiatan bisnis bertujuan pada perolehan laba agar dapat digunakan sebagai sumber untuk menjaga kelangsungan hidup serta perkembangan perusahaan. Pencapaian laba dapat terealisasi apabila perusahaan juga melakukan perencanaan terhadap target volume penjualan. Proses untuk mencapai target laba yang diinginkan tentu berkaitan dengan perencanaan yang ditetapkan guna memenuhi kebutuhan kegiatan operasionalnya di masa yang akan datang. Pencapaian target laba perusahaan berkaitan dengan jumlah produk yang dijual serta besaran harga yang ditetapkan.

Untuk meningkatkan pelayanan masyarakat dalam memenuhi kebutuhan air minum, perlu dibangun tambahan infrastruktur produksi dan distribusi air bersih yang sudah ada. Oleh sebab itu, untuk memenuhinya dibutuhkan biaya yang sangat besar baik dari perusahaan sendiri ataupun dari pihak luar baik itu untuk kebutuhan investasi, operasional, maintenance, serta lainnya. Investasi yang telah dikeluarkan, harapan utamanya adalah mendapatkan hasil berupa keuntungan (laba). Jadi, untuk setiap biaya yang telah dikeluarkan perlu mengikuti analisa pemulihan biaya penuh (Full Cost Recovery). Dalam arti lain Full Cost Recovery merupakan keinginan dari owner atau investor atas terjaminnya biaya yang telah dikeluarkan (investasi, operasional, maintenance, serta bunga dan keuntungan yang sewajarnya) akan kembali (mendapatkan laba).

Dalam konteks Perusahaan Daerah Air Minum (PDAM), pencapaian target laba ditentukan oleh jumlah air yang dijual kepada pelanggan serta tarif retribusi (harga) penggunaan air. Volume penjualan air minum dan tarif retribusi air merupakan cara untuk memperkiraan dalam volume penjualan berapa perusahaan dapat menutup seluruh biaya yang dikeluarkan. Perusahaan Daerah Air Minum (PDAM) Kota Blitar saat ini melayani $\pm 26 \%$ dari penduduk Kota Blitar dengan kemampuan suplay 79 liter/detik. Perbandingan antara besaran tarif dengan jumlah air terjual perlu diketahui untuk merencanakan besaran laba yang harus/akan diperoleh perusahaan. Untuk itu perlu dilakukan suatu kajian mengenai kelayakan tarif untuk Perusahaan Daerah Air Minum (PDAM) Kota Blitar berdasarkan pengembalian biaya penuh (Full Cost Recovery).

Dari latar belang diatas penulis melakukan penelitian dengan judul "Analisa Kelayakan Tarif Pada Perusahaan Daerah Air Minum (PDAM) 
Kota Blitar, JawaTimur Berdasarkan Pengembalian Biaya Penuh (Full Cost Recovery)"

\section{Perumusan Masalah}

Perumusan masalah dalam penelitian ini adalah "Bagaimanakah penetapan harga jual (tarif) air minum pada Perusahaan Daerah Air Minum (PDAM) Kota Blitar agar dapat menutup seluruh biaya perusahaan?"

\section{Tujuan dan Manfaat Penelitian}

\section{TujuanPenelitian}

Tujuan yang ingin dicapai dari penelitian ini yaitu untuk mendapat kan gambaran tentang penetapan harga jual (tarif) air minum pada Perusahaan Daerah Air Minum (PDAM) Kota Blitar agar dapat menutup seluruh biaya perusahaan.

\section{ManfaatPenelitian}

1. Manfaat bagi Perusahaan Daerah Air Minum (PDAM) Kota Blitar :dapat dipergunakan sebagai bahan pertimbangan dalam penetapan harga jual (tarif) air minum per satuan $\left(\mathrm{m}^{3}\right)$

2. Manfaat bagi peneliti : dapat dijadikan media belajar penelitian guna perbaikan-perbaikan penelitian yang pernah dilakukan sebelumnya.

3. Manfaat bagi pengembangan ilmu pengetahuan :dapat dijadikan pengujia nempirik atas penetapan harga jual (tarif) pernah dilakukan sebelumnya.

4. Manfaat bagi peneliti lainnya :dapat dipergunakan sebagai referensi dan bahan perbandingan untuk penelitian-penelian pada perusahaan yang sejenis.

\section{Landasan Teori}

\subsection{Pengertian Biaya}

Biaya adalah pengorbanan sumber ekonomi, yang diukur dalam satuan uang. Yang telah terjadi atau yang kemungkinan terjadi untuk tujuan tertentu ( Mulyadi, 1991 : 8 - 9). Biaya dapat diartikan sebagai kas/ekuivalen kas yang dikorbankan untuk mendapatkan barang atau jasa yang diharapkan memberi manfaat saat ini atau jasa yang diharapkan member manfaat saat ini atau dimasa yang akan datang bagi organisasi (Hansen, Mowen, 2004 : 40). Biaya adalah sumber ekonomi yang dikorbankan untuk mencapai sasaran tertentu ( Horngren, 1994 : 28)..

Biaya adalah kas atau nilai setara kas yang dikorbankan untuk mendapatkan barang atau jasa yang diharapkan memberi manfaat saat ini atau di masa depan bagi organisasi (Hansen dan Mowen, 2012:46). Biaya didefinisikan sebagai manfaat (benefit) yang dikorbankan dalam rangka memperoleh barang dan jasa (Kusnadi, 
dkk, 2005:136)

Dari beberapa pengertian biaya diatas dapat disimpulkan bahwa biaya adalah sesuatu yang dikeluarkan untuk membiayai suatu kegiatan tertentu dimana dengan biaya tersebut akan diperoleh manfaat.

\subsection{Klasifikasi Biaya}

Dalam mengklasifikasikan biaya, menurut Mulyadi dalam bukunya "Akuntansi Biaya" menggolongkan biaya kedalam lima klasifikasi yaitu sebagai berikut:

1. Penggolongan biaya menurut objek biaya

2. Penggolongan biaya menurut fungsi pokok dalam perusahaan

3. Penggolongan biaya menurut hubungan biaya dengan sesuatu yang dibiayai

4. Penggolongan biaya menurut perilakunya dalam hubungannya dengan perubahan volume kegiatan

5. Penggolongan biaya atas dasar jangka waktu manfaatnya.(2001: 45)

Dalam lima klasifikasi biaya diatas, didefinisikan sebagai berikut:

1. Penggolongan biaya menurut objek biaya : Nama objek pengeluaran merupakan dasar penggolongan biaya. Misalnya objek pengeluaran adalah bahan bakar, maka semua pengeluaran yang berhubungan dengannya disebut biaya bahan bakar.

2. Penggolongan biaya menurut fungsi pokok dalam perusahaan Biaya dikelompokan menjadi tiga kelompok fungsi pokok dalam perusahaan yaitu:

a) Biaya Produksi

Merupakan biaya-biaya yang terjadi untuk mengolah bahan baku produk jadi. Menurut objek pengeluarannya, secara garis besar biaya produksi dibagi menjadi biaya bahan baku, biaya tenaga kerja langsung dan biaya overhead pabik.

b) Biaya Pemasaran

Merupakan biaya-biaya yang terjadi untuk melaksanakan kegiatan pemasaran produk. Contohnya biaya iklan, biaya promosi, gaji karyawan bagian pemasaran dan sebagainaya

c) Biaya Administrasi dan Umum

Merupakan biaya-biaya untuk mengkoordinasikan kegiatan produksi dan pemasaran produk

3. Penggolongan biaya menurut hubungan biaya dengan sesuatu yang dibiayai Dapat dikelompokan menjadi dua golongan yaitu:

a. Biaya Langsung (Direct Cost)

Biaya yang terjadi, penyebab satu-satunya adalah karena adanya sesuatu yang dibiayai. Jika sesuatu yang dibiayai tersebut tidak ada, maka biaya langsung tidak akan terjadi. 
b. Biaya Tidak Langsung (Indirect Cost)

Biaya yang terjadi hanya disebabkan oleh sesuatu yang dibiayai. Biaya ini dalam hubungan dengan produk disebut dengan istilah biaya produksi tidak langsung atau biaya overhead pabrik

4. Penggolongan biaya menurut perilakunya dalam hubungannya dengan perubahan volume kegiatan. Dalam hubungannya dengan perubahan volume kegiatannya, biaya dapat digolongkan menjadi:

a. Biaya Variabel

Merupakan biaya yang jumlah totalnya berubah sebanding dengan perubahan volume kegiatan. Contohnya biaya bahan baku dan biaya tenaga kerja.

b. Biaya Semi Variabel

Biaya Semi Variabel adalah biaya yang berubah tidak sebanding dengan perubahan volume kegiatan. Biaya ini mengandung unsur biaya tetap dan unsur biaya variabel

c. Biaya Semi Fixed

Merupakan biaya yang tetap untuk tingkat volume kegiatan tertentu dan berubah dengan jumlah yang konstan pada volume produksi tertentu.

d. Biaya Tetap

Merupakan biaya yang jumlah totalnya tetap dalam kisar volume kegiatan tertentu.

5. Penggolongan biaya atas dasar jangka waktu manfaatnya

a. Pengeluaran Modal (Capital Expenditurs)

Pengeluaran modal adalah biaya yang mempunyai manfaat lebih dari satu periode akuntansi (Biasanya periode akuntansi adalah satu tahun kalender). Pengeluaran modal ini pada saat terjadinya dibebankan sebagai harga pokok aktiva dan dibebankan dalam tahun-tahun yang dinikmati manfaatnya dengan cara didepresiasi atau diamortisasi.

b. Pengeluaran Pendapatan (Revenue Expenditurs) Merupakan biaya yang hanya mempunyai manfaat dalam periode akuntansi terjadinya pengeluaran tersebut

\subsection{Break Even Point}

Break Even Point atau titik impas merupakan suatu titik yang menunjukkan bahwa pendapatan total yang dihasilkan perusahaan sama dengan jumlah biaya yang dikeluarkan, sehingga perusahaan tidak memperoleh laba dan tidak mengalami kerugian. Break Even Point dapat diartikan suatu keadaan dimana dalam operasi, perusahaan tidak memperoleh laba dan tidak menderita rugi (penghasilan = total biaya) $($ Munawir, 2007:184). 
Break Even Point dapat diartikan suatu keadaan dimana dalam operasi perusahaan, perusahaan tidak memperoleh laba dan tidak menderita rugi (penghasilan yangdinilai menggunakan total biaya). Metode Break Even Point(BEP) tidak hanya semata-mata untukmengetahui keadaan perusahaan apakah mencapai titik Break Even Point(BEP), akan tetapi metode Break Even Point(BEP)mampu memberikan informasi kepada pimpinan perusahaan mengenai berbagai tingkat volume penjualan, serta hubungannya dengan kemungkinanmemperoleh laba menurut tingkat penjualan yang bersangkutan.

Definisi Break Even Point dari pendapat berbagai ahli terlihat adakesamaan diantaranya pendapat-pendapat tersebut adalah :

1. Menurut Bambang Riyanto (1995:359). Analisis Break Even Pointadalah suatutehnik analisis untuk mempelajari hubungan antara biaya tetap, biaya variabel,keuntungan dan volume kegiatan. Oleh karena analisis tersebut mempelajarihubungan antara biaya "Keuntungan-Volume-Kegiatan", maka analisis tersebut sering pula disebut" Cost - Profit - Volume analysis (C.P.V analysis)".

2. Dalam perencanaan keuntungan, analisis Break Even Point merupakan "Profit - Planning Approach" yang mendasarkan pada hubungan antara biaya (cost) dan penghasilan penjualan (revenue).

3. Menurut Hansen dan Mowen (2005:274) dalam buku terjemahan"Management Accounting"menyebutkan "Break Even Pointadalah titik dimana total pendapatan sama dengan total biaya, titik dimana laba sama dengan nol".

Dari beberapa pengertian di atas dapat disimpulkan dengan katalain, pada keadaan Break Even Poinkeuntungan atau kerugian sama dengan nol (0) yaitu:

a. Suatu kondisi dimana perusahaan tidak memperoleh laba dan tidak menderitakerugian, atau

b. $T R$ (Total Revenue) $=T C$ (Total Cost), dimana laba $=0$

Analisis Break Even Point merupakan suatu analisis yang digunakan oleh manajemen sebagai acuan pemberian keputusan terhadap perencanaan keuangan, khususnya pada tingkat laba yang ingin dicapai serta berhubungan dengan tingkat penjualannya. Manajemen perlu mengetahui hubungan antara biaya, volume penjualan dan laba sebagai dasar informasi penunjangnya. Semaksimal mungkin perusahaan akan terus berupaya untuk menghindari kerugian walaupun juga tidak mendapatkan laba,

namun tetap berada pada keadaan Break Even. 
Zahir mengatakan bahwa Break Even Point (BEP) adalah titik impas di mana keadaan jumlah pendapatan dan biaya sama atau seimbang sehingga tidak terdapat keuntungan ataupun kerugian. (http://zahiraccounting.com/id/blog/break-even-point-bep/)

Break Even Point (BEPini digunakan untuk menganalisis proyeksi sejauh mana banyaknya jumlah unit yang diproduksi atau sebanyak apa uang yang harus diterima untuk mendapatkan titik impas atau kembali modal.

\subsection{Manfaat Analisis Break Even Point}

Matzh (1997: 224) juga menjelaskan beberapa manfaat analisaBreak Even Point (BEP) untuk manajemen, antara lain:

1. Membantu pengendalian melalui anggaran (Budgetery Contro) . Membantu menunjukkan perubahan apabila ada yang diperlukan untuk menjadikan biaya selaras dengan pendapatan.

2. Meningkatkan dan menyeimbangkan penjualan. Berlaku sebagai sinyal peringatan untuk mengubah manajemen terhadap kemungkinan kesulitan dalam program penjualan. Jika penjualan secara relatif tidak cukup tinggi dibandingkan dengan biasanya seperti semestinya, kenyataan ini akan diperhatikan. Dengan demikian akan tersedia cukup waktu guna mengevaluasikembali teknik penjualan

Manfaat lainnya menggunakan metode Break Even Pointmenurut Bambang Soepeno (2012: 3) adalah sebagai Perencanaan Penjualan atau Produksi pada setiap awal periode perusahaan sudah harus mempunyai perencanaan produksi dan penjualan. Rencana produksi dan penjualan bisa direncanakandengan menggunakan konsep Break Even Point (BEP). Penjualan yang direncanakan perusahaantentunya disertai dengan target laba yang diinginkan. Dengan demikianrencana Penjualan Minimal (PM) adalah :

\subsection{Metode Perhitungan Break Even Point}

1) Metode Grafik

Menggambarkan suatu titik impas dalam grafik perlu digambarkan adanya garis penjualan. Penjualan ini merupakan hasil perkalian antara volume produksi/penjualan (dalam unit) dengan harga jual per unit.

2) Metode Matematis

$\mathrm{BEP}=\mathrm{FC} /(\mathrm{P}-\mathrm{VC})$

Sumber: Djarwanto (2010:217)

3) Break Even Point dihitung dengan metode Marjin Kontribusi 
Marjin Kontribusi (Contribution Margin) adalah jumlah pendapatan yang tersisa setelah dikurangi dengan biaya variabel Mencari nilai titik impas dengan metode marjin kontribusi yaitu, jumlah biaya tetap harus dibagi dengan marjin kontribusi yang dihasilkan oleh setiap unit yang terjual.

Dasar Unit Berapa unit jumlah barang/jasa yang harus dihasilkan untuk mendapat titik impas: $\mathrm{BEP}=\mathrm{FC} /(\mathrm{P}-\mathrm{VC})$

Dasar Penjualan Berapa rupiah nilai penjualan yang harus diterima untuk mendapat titik impas: FC/ $(1-(\mathrm{VC} / \mathrm{P}))^{\star}$ Penghitungan (1 $(\mathrm{VC} / \mathrm{P})$ ) biasa juga disebut dengan istilah Margin Kontribusi Per Unit. Untuk membuktikan bahwa dengan menjual 9.000 unit perusahaan akan mendapatkan laba Rp 720 juta, mari kita periksa berikut ini:

Penjualan Rp 720.000.000

FC Rp 100.000.000

Total VC (Rp 60.000 x 9000 unit) Rp 540.000.000

Total Biaya Rp 640.000.000

Laba Rp 80.000.000

Berapa unit jumlah barang/jasa yang harus dihasilkan untuk mendapat titik impas:BEP = FC /(P-VC)

Berapa rupiah nilai penjualan yang harus diterima untuk mendapat titik impas:FC/ $(1-(\mathrm{VC} / \mathrm{P}))$ * Penghitungan $(1-(\mathrm{VC} / \mathrm{P}))$ biasa juga disebut dengan istilah Margin Kontribusi Per Unit.

Agar bisa memahaminya, mari kita praktikkan langsung rumus ini dengan simulasi:

Total Biaya Tetap senilai Rp 100 juta

Total Biaya Variabel per unit senilai Rp 60 ribu

Harga jual barang per unit senilai Rp 80 ribu

Penghitungan BEP Unit

$\mathrm{BEP}=\mathrm{FC} /(\mathrm{P}-\mathrm{VC})$

$\mathrm{BEP}=100.000 .000 /(80.000-60.000)$

$\mathrm{BEP}=\operatorname{Rp} 5000$

Penghitungan BEP Rupiah

$\mathrm{BEP}=\mathrm{FC} /(1-(\mathrm{VC} / \mathrm{P}))$

$\mathrm{BEP}=100.000 .000 /(1-(60.000 / 80.000))$

$\mathrm{BEP}=\mathrm{Rp} 400.000 .000$

Dari analisis inilah perusahaan dapat meramalkan keuntungan yang dapat diperoleh (target laba) berdasarkan berapa penjualan minimumnya. Adapun rumus untuk menghitung target ini sebagai berikut:

$\mathrm{BEP}+\mathrm{Laba}=(\mathrm{FC}+$ Target Laba $) /(\mathrm{P}-\mathrm{VC})$

Mari kita pelajari simulasi untuk menghitung target laba ini. Dengan $\mathrm{FC}, \mathrm{VC}$, dan $\mathrm{P}$ yang sama dengan contoh sebelumnya, perusahaan ini menargetkan laba sebesar Rp 80 juta per bulan.

$\mathrm{BEP}+\mathrm{Laba}=(\mathrm{FC}+$ Target Laba $) /(\mathrm{P}-\mathrm{VC})$ 


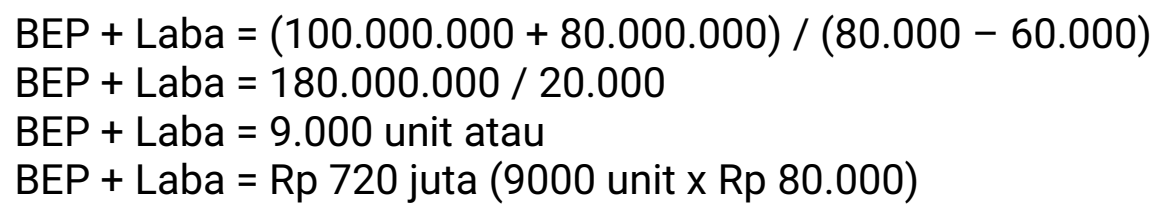

\subsection{Metode Full Costing}

Menurut Samryn $(2001,63)$ adalah metode penentuan harga pokok yang mempertimbangkan semua biaya produksi yang terdiri dari biaya bahan baku,biaya tenaga kerja,dan biaya overhead tetap maupun variabel.

Lebih lanjut Rifqi (2014) menjelaskan bahwa metode penentuan harga pokok produksi yang memperhitungkan semua unsur biaya produksi ke dalam harga pokok produksi yang terdiri dari biaya bahan baku,biaya tenaga kerja langsung dan biaya overhead pabrik variabel dan biaya overhead pabrik tetap) ditambah dengan biaya non produksi (biaya pemasaran,biaya administrasi dan umum)

Zahir mengatakan bahwa BEP memerlukan komponen penghitungan dasar seperti:

Fixed Cost : Komponen ini merupakan biaya yang tetap atau konstan jika adanya tindakan produksi atau meskipun perusahaan tidak berproduksi. Contoh biaya ini yaitu biaya tenaga kerja, biaya penyusutan mesin, dll.

Variable Cost : Komponen ini merupakan biaya per unit yang sifatnya dinamis tergantung dari tindakan volume produksinya. Jika produksi yang direncanakan meningkat, berarti variable cost pasti akan meningkat. Contoh biaya ini yaitu biaya bahan baku, biaya listrik, dll.

Selling Price: Komponen ini adalah harga jual per unit barang atau jasa yang telah diproduksi.(http://zahiraccounting.com/id/blog/break-even-point-b ep/)

\section{Regresi Linear Sebagai Alat Bantu Pemisahan Biaya Semi Variabel menjadi Biaya Tetap dan Biaya Variabel}

Regresi linear sederhana didasarkan pada hubungan fungsional ataupun kausal

antara satu variabel independen dengan satu variabel dependen.

Persamaan umum regresi linier sederhana adalah :

$Y=a+b X$

harga $b$ merupakan fungsi dari koefisien korelasi. Bila koefisien korelasi tinggi, maka harga $b$ juga besar, sebaliknya bila koefisien korelasi rendahmaka harga b juga renah (kecil). Selain itu bila koefisien korelasi negatif makaharga $b$ juga negatif, dan sebaliknya bila koefisien korelasi positif maka harga bjuga positif.

Selain itu harga a dan $\mathrm{b}$ dapat dicari dengan rumus berikut : 


$$
\begin{aligned}
& a=\frac{\sum\left(Y_{i}\right)\left(\sum X_{i}^{2}\right)-\left(\sum X_{i}\right)\left(\sum X_{i} \sum Y_{i}\right)}{n \sum X_{i}^{2}-\sum\left(X_{i}\right)^{2}} \\
& b=\frac{n \sum X_{i} Y_{i}-\left(\sum X_{i}\right)\left(\sum Y_{i}\right)}{n \sum X_{i}^{2}-\left(\sum X_{i}\right)^{2}} \\
& \text { Keterangan : } \\
& Y=\text { biaya semi variabel } \\
& a=\text { biaya tetap } \\
& b=\text { biaya variabel } \\
& X=\text { jumlah unit yang terjual }
\end{aligned}
$$

\subsection{Tarif PDAM}

Berdasarkan peraturan menteri dalam negeri nomor 23 tahun 2006 tentang pedoman teknis dan tata cara pengaturan tariff air minum pada perusahaan daerah air Minum (PDAM). Tariff diefinisikan sebagai kebijakan harga jual air minum dalam setiap meter kubik (m3 ) atau satuan volume lainnya sesuai kebijakan yang ditentukan Kepala Daerah dan PDAM yang bersangkutan.

Mekanisme penetapan tariff didasarkan atas asas proporsionalitas kepentingan:

1. Masyarakat Pelanggan

2. PDAM Selaku badan usaha dan Penyelenggara,dan

3. Pemerintah daerah selaku pemilik PDAM

Permendagri Nomor 23 tahun 2006 menerapka prinsip pemulihan biaya penuh (full cost recovery).Prinsip ini mengandung misi bahwa PDAM diharapkan mampu menghasilkan pendapatan tariff yang nilai minimalnya dapat menutupi seluruh biaya operasional (Biaya penuh).Dengan ketentuanpendapatan biaya minimal tersebut,PDAM diharapkan mampu mempertahankan dan meningkatkan kuantitas, kualitas dan kontinuitas pelayanannya kepada masyarakat.

Penetapan Tarif ini harus dilakukan secara transparan dan akuntabel.Prinsip transparan berarti PDAM harus menyampaika secara jelas dan terbuka informasi proses perhitungan dan penetapan tariff itu seperti apa.

\subsection{Kerangka konsepsual}

\section{GAMBAR KERANGKA KONSEPSUAL}

HARGA

JUAL

\section{BEBAN USAHA}

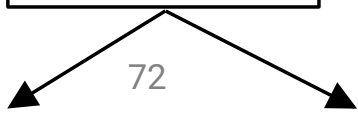




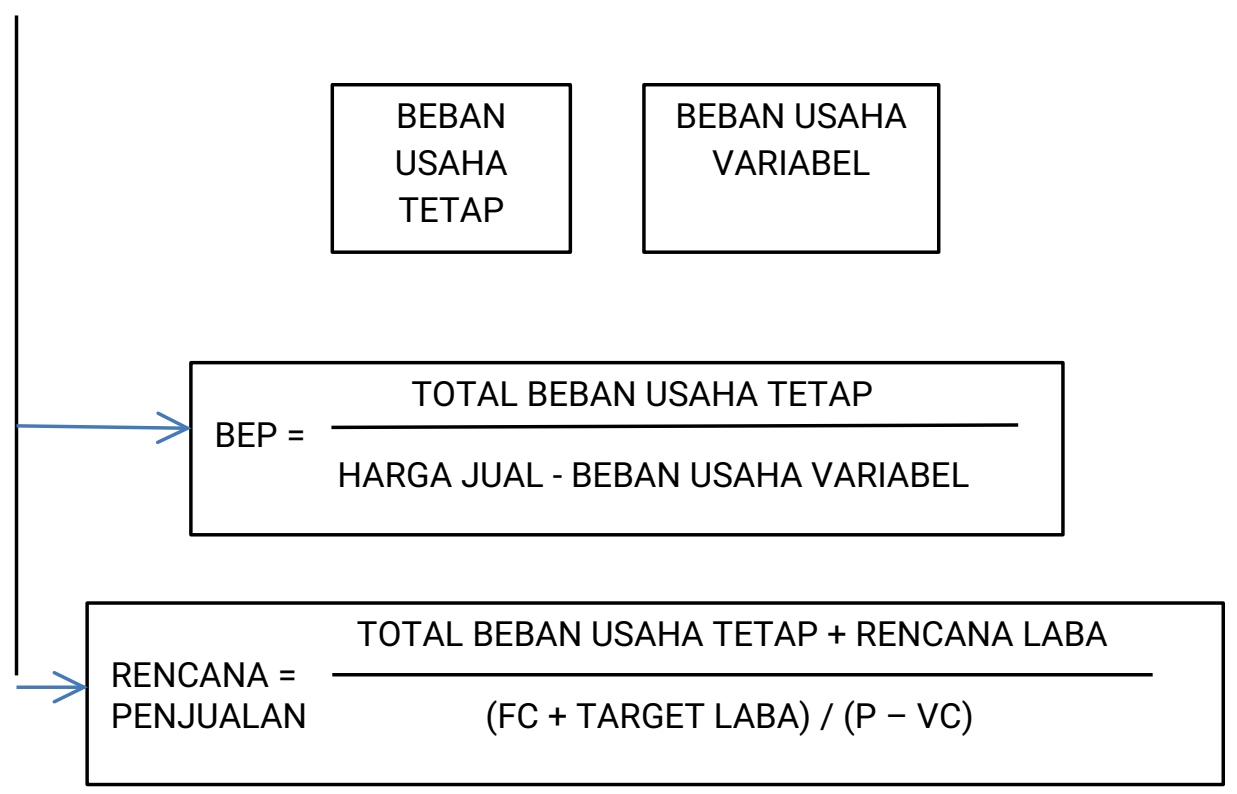

\section{METODE PENELITIAN}

\subsection{Jenis Penelitian}

Karya ilmiah dalam penelitian ini merupakan studi kasus (cases study) pada Perusahaan Daerah Air Minum (PDAM) Kota Blitar, JawaTimur, khusunya tentang penetapan Break Even Point.

\subsection{Teknik Pengambilan Sampel}

Dalam studi kasus tidak menggunakan sampel dalam penganalisaannya.

\subsection{Variabel Penelitian Dan Definisi Operasional}

Fixed Cost (biayatetap) : adalah biaya yang tetap atau konstan jika adanya tindakan produksi atau meskipun perusahaan tidak berproduksi

Variabel Cost (biaya variable) : adalah biaya per unit yang sifatnya dinamis tergantung dari tindakan volume produksinya. Jika produksi yang direncanakan meningkat, berarti variable cost pasti akan meningkat.

Selling Price (hargajual) :adalah harga jual per unit barang atau jasa yang telah diproduksi.

\subsection{Teknik Analisis}

Penganalisaan dilakukan beberapa tahapan pengolahan data:

1. Pemisahan Beban Usaha menjadi Beban Usaha Tetap dan Beban Usaha Variabel.

2. Penghitungan Break Even Point (BEP) baik dalam unit maupun rupiah, dengan menggunakan rumus :

Dalam Unit: BEP $=\mathrm{FC} /(\mathrm{P}-\mathrm{VC})$

Dalam rupiah : $\mathrm{FC} /(1-(\mathrm{VC} / \mathrm{P}))$ 
HASIL PENELITIAN

\subsection{Hasil Penjualan, Beban Usaha dan Laba (Rugi)}

REK APITULAS HASIL PEN JUALAN AIR MINUM

PERIODE 2011-2014

\begin{tabular}{|c|c|c|c|c|}
\hline \multirow[b]{2}{*}{ HASIL PEN JUALAN } & 2011 & 2012 & 2013 & 2014 \\
\hline & $\mathrm{Rp}$ & $\mathrm{Rp}$ & $\mathrm{Rp}$ & $\mathrm{Rp}$ \\
\hline $\mathrm{N}$ on $\mathrm{N}$ iaga & $2,153,820,100$ & $2,291,325,100$ & $2,250,853,900$ & $2,420,729,600$ \\
\hline $\mathrm{N}$ iaga & $172,955,100$ & $160,687,200$ & $144,696,600$ & $134,151,300$ \\
\hline Sosial & $39,884,450$ & $38,819,750$ & $36,620,500$ & $40,765,850$ \\
\hline Instansi Pemerintah & $197,215,000$ & $159,554,100$ & $187,147,050$ & $125,282,100$ \\
\hline $\mathrm{K}$ ran Umum & $4,961,950$ & $6,773,400$ & $6,802,100$ & $6,233,850$ \\
\hline JUM LAH HASIL PEN JUAL & $2,568,836,600$ & $2,657,159,550$ & $2,626,120,150$ & $2,727,162,700$ \\
\hline \multicolumn{5}{|l|}{ BEBAN USAHA } \\
\hline Jumlah B eb an U saha T etap & $4,173,582,587$ & $3,590,818,005$ & $5,955,008,766$ & $4,777,503,791$ \\
\hline Jumlah B eb an U saha V ariabel & $568,386,540$ & $521,946,380$ & $628,096,865$ & $666,055,463$ \\
\hline JUM LAH BEBAN USAHA & $4,741,969,127$ & $4,112,764,385$ & $6,583,105,631$ & $5,443,559,254$ \\
\hline LABA (RUG I) USAHA & $(2,173,132,527)$ & $(1,455,604,835)$ & $(3,956,985,481)$ & $(2,716,396,554)$ \\
\hline
\end{tabular}

PD A M K ota B litar, 31 D esember 2011-2014

Dari tabel di atas dapat dilihat bahwa dari tahun 2011 sampai dengan 2014 Perusahaan Daerah Air Minm (PDAM) Kota Blitar menderita rugi yaitu secara berturut-turut dari tahun 2011-2014 adalah : Rp 2.173.132.527,-, $\quad$ Rp 1.455.604.835,-, $\quad R p$ 3956.985.481,- dan Rp 2.716.396.554,-

Hal ini terjadi karena PDAM lebih banyak menekankan kepada fungsi sosial, pelayanan kepada masyarakat kota Blitar.

Namun dari sisi kelangsungan hidup serta perkembangan perusahaan kondisi ini tidak dibenarkan, atau tidak dapat dipertahankan, karena bagaimanapun juga untuk mempertahankan kelangsungan hidup dan perkembangan usaha membutuhkan sumber-sumber dana dari hasil usaha.

Sebagai salah satu upaya yang dapat dilakukan untuk berbenah diri, tidak tergantung kepada Pemerintahan Kota Blitar , Pemerintahan Provinsi Jawa Timur, atau instansi pemerintah lainnya serta sumber hibah yang ada, maka prinsip-prinsip bisnis (usaha) harus dilakukan dengan sebaik-baiknya.

Langkah-langkah yang sebaiknya ditempuh untuk menuju kemandirian badan usaha ini diantaranya adalah setiap aktivitas bisnisnya harus berprinsip kepada "Cost and Benevit", yaitu pengorbanan harus lebih kecil dari kemanfaatan, prinsip ekonomi dijalankan, yaitu dengan pengorbanan tertentu untuk mendapatkan hasil yang sebesar-besarnya, dan dengan hasil tertentu harus dengan pengorbanan biaya yang sekesil-kecilnya, jika dibuat sutu alur berfikir sebagai berikut :

Pendapatan Hasil Usaha $\quad \mathrm{Rp} X X X$ 
$\frac{\text { Beban- Beban Usaha }}{\text { Laba }} \frac{\operatorname{Rp~XXX}}{\operatorname{Rp~XXX}}-$

Dari alur di atas dapat dilihat beberapa alternatif penyelesaiannya, yaitu : meningkatkan Pendapatan Hasil Usaha dengan meningkatkan jumlah pelanggan, dan atau dengan menaikkan harga jual (tarif) per $\mathrm{m}^{3} \mathrm{nya}$, dan atau meningkatkan effisiensi atau menekan biaya sedemikian rupa sehingga tanpa menaikkan harga jual (tarif) sudah bisa mendapatkan keuntungan (laba).

Namun untuk menekan beban usaha, sangat sulit dilakukan, karena beban usaha yang selama ini dikeluarkan sudah melalui perhitungan yang cermat dengan prinsip efektivitas dan efisiensi.

Cara lain untuk bisa mendapatkan keuntungan, atau sebagai tahap awal sementara ini dicoba diterapkan konsep Titik Impas, atau Break Even Point, dimana pada kondisi ini perusahaan tidak mengalami kerugian serta tidak mendapatkan keuntungan (laba), keuntungan atau kerugian = 0 (nol)

Melihat pada Kerangka Konsepsal, seperti yang telah diutarakan dimuka, bahwa Analisa Titik Impas (Break Even Point) membutuhkan data, informasi Harga Jual,

Biaya Tetap, Biaya Variabel.

Tarif Dan Volume Penjualan Air Minum

Pdam Kota Blitar Tahun 2011-2014

\begin{tabular}{|l|l|l|}
\hline TAHUN & TARIF $(\mathrm{Rp})$ & VOLUME PENJUALAN $\left(\mathrm{m}^{3}\right)$ \\
\hline 2011 & 2.177 & 1.013 .436 \\
\hline 2012 & 2.928 & 984.600 \\
\hline 2013 & 3.320 & 959.613 \\
\hline 2014 & 3.320 & 995.327 \\
\hline Jumlah & 11.744 & 3.952 .976 \\
\hline Rata-Rata & $2.935,88$ & $988.243,94$ \\
\hline
\end{tabular}

Sumber : BPKP Perwakilan Provinsi Jawa Timur, Laporan Hsil Audit Kinerja PDAM Kota Blitar, Tahun Buku 2011, 2012, 2013 dan 2014

Rata-Rata Harga Jual (Tarif) Tahun 2011-2014 per m3 $=\quad$ Rp 2.935,88 Jumlah unit (satuan) yang terjual Tahun 2011-2014 =3.952.976 $\mathrm{m}^{3}$ Rata-Rata Beban Usaha Tetap Tahun2011-2014 = Rp4,624,228,287.39 Total Beban Usaha Variabel Tahun 2011-2014 = Rp 2.384.485.248,Rata-Rata Beban Usaha Variabel Tahun 2011-2014 = Rp 603,21

Analisa Titik Impas atau Break Even Point dihitung dengan bantuan rumus sebagai berikut:

Dalam Unit: BEP = FC /(P-VC)

Dalam rupiah : $\quad$ BEP $\left(\mathrm{m}^{3}\right) \times$ Tarif (Harga Jual) per $\mathrm{m}^{3}$

$\mathrm{BEP}$ (unit) rata-rata per tahun 
$=\operatorname{Rp} 4,624,228,287.39 /(\operatorname{Rp} 2.935,88-\operatorname{Rp} 603,21)$

$$
=1,982,367 \mathrm{~m}^{3}
$$

$\operatorname{BEP}(\mathrm{Rp})=1,982,367 \mathrm{~m} 3 \times \mathrm{Rp} 2.935,88$

$$
=\mathrm{Rp} 5,819,992,173.97
$$

Rekapitulasi Volume Penjualan Air Minum

\begin{tabular}{|c|c|c|c|c|c|c|c|c|c|}
\hline \multirow{2}{*}{$\begin{array}{l}\text { KelompokPelangg } \\
\text { an }\end{array}$} & \multicolumn{2}{|l|}{2011} & \multicolumn{2}{|l|}{2012} & \multicolumn{2}{|l|}{2013} & \multicolumn{2}{|l|}{2014} & \multirow{2}{*}{$\begin{array}{l}\text { Rata-R } \\
\text { ata (\%) } \\
2011-2 \\
014\end{array}$} \\
\hline & $\mathrm{m}^{3}$ & $\%$ & $\mathrm{~m}^{3}$ & $\%$ & $\mathrm{~m}^{3}$ & $\%$ & $\mathrm{~m}^{3}$ & $\%$ & \\
\hline Non Niaga & 898,023 & 89 & $\begin{array}{l}878,30 \\
4\end{array}$ & 89 & $\begin{array}{l}850,70 \\
6\end{array}$ & 89 & $\begin{array}{l}542,28 \\
5\end{array}$ & 87 & 88 \\
\hline Niaga & 29,826 & 3 & 27,312 & 3 & 24,455 & 3 & 22,723 & 4 & 3 \\
\hline Sosial & 29,130 & 3 & 21,005 & 2 & 19,543 & 2 & 21,755 & 3 & 3 \\
\hline $\begin{array}{l}\text { InstansiPemerinta } \\
\text { h }\end{array}$ & 56,457 & 6 & 25,795 & 3 & 43,867 & 5 & 29,366 & 5 & 4 \\
\hline HanKam & 0 & 0 & 25,105 & 3 & 13,871 & 1 & 0 & 0 & 1 \\
\hline KranUmum & 0 & 0 & 7,079 & 1 & 7,171 & 1 & 6,572 & 1 & 1 \\
\hline JUMLAH & $\begin{array}{l}1,013,43 \\
6\end{array}$ & $\begin{array}{l}10 \\
0\end{array}$ & $\begin{array}{l}984,60 \\
0\end{array}$ & 100 & $\begin{array}{l}959,61 \\
3\end{array}$ & $\begin{array}{l}10 \\
0\end{array}$ & $\begin{array}{l}622,70 \\
2\end{array}$ & $\begin{array}{l}10 \\
0\end{array}$ & 100 \\
\hline
\end{tabular}
PERIODE 2011-2014 $\left(\mathrm{M}^{3}\right)$

Sumber : BPKP PerwakilanProvinsiJawaTimur, LaporanHsil Audit Kinerja PDAM Kota Blitar, TahunBuku 2011, 2012, 2013 dan 2014, diolah.

Dalam kondisi Break Even Point (Titik Impas) komposisi masing-masing kelompok pelanggan adalah seperti pada table berikut ini KOMPOSISI BREAK EVENT POINT PER KELOMPOK PELANGGAN KOMPOSISI BREAK EVENT POINT PER KELOMPOK PELANGGAN

\begin{tabular}{|l|l|l|l|l|}
\hline KelompokPelanggan & Rata-Rata (\%) & BEP (Rupiah) & Tarif & BEP $\left(\mathrm{m}^{3}\right)$ \\
\hline Non Niaga & 88 & $5,144,184,344$ & $\begin{array}{l}2,57 \\
5\end{array}$ & $1,752,178$ \\
\hline Niaga & 3 & $173,278,219$ & $\begin{array}{l}5,87 \\
9\end{array}$ & 59,021 \\
\hline Sosial & 3 & $153,264,887$ & $\begin{array}{l}1,74 \\
1\end{array}$ & 52,204 \\
\hline InstansiPemerintah & 4 & $254,273,905$ & $\begin{array}{l}3,79 \\
0\end{array}$ & 86,609 \\
\hline HanKam & 1 & $58,199,922$ & $\begin{array}{l}2,91 \\
7\end{array}$ & 19,824 \\
\hline KranUmum & 1 & $36,744,376$ & 713 & 12,516 \\
\hline
\end{tabular}


Jumlah

Sumber : BPKP PerwakilanProvinsiJawaTimur, LaporanHsil Audit Kinerja PDAM Kota Blitar, TahunBuku 2011, 2012, 2013 dan 2014, diolah.

Rata-Rata Hasil Penjualan Air Minum Perusahaan Daerah Air Minum (PDAM) Kota Blitar Per tahun Tingkat Break Even Point $=\mathrm{Rp} 2,644,894,750$,-

Subsidi PemDa Per Tahun = = Rp3,175,050,902,-

Secara prinsip Full Cost Recovery pada tingkat Break Even Point ini, maka semua beban usaha yang seharusnya ditutup dari sumber eksternal, atau dari pihak luar, berupa subsidi Pemerintah Kota Blitar dana tau Pemerintah Provinsi Jawa Timur adalah sebesar Rp3,175,050,902,-, dengan komposisi distribusi untuk masing-masing kelompok pelanggan adalah seperti pada table berikut ini:

Komposisi Perolehan Subsidi Posisi Break Event Point

Per Kelompok Pelanggan Per Tahun

\begin{tabular}{|l|l|l|}
\hline KelompokPelanggan & $\begin{array}{l}\text { Rata-Rata } \\
(\%)\end{array}$ & Rupiah \\
\hline Non Niaga & 88 & $\begin{array}{c}2,806,369,26 \\
1\end{array}$ \\
\hline Niaga & 3 & $94,530,568$ \\
\hline Sosial & 3 & $83,612,452$ \\
\hline InstansiPemerintah & 4 & $138,717,127$ \\
\hline HanKam & 1 & $31,750,509$ \\
\hline KranUmum & 1 & $20,045,605$ \\
\hline Jumlah & 100 & $3,175,025,52$ \\
\hline & &
\end{tabular}


Rata-rata beban usaha Tetap dan Variabel per tahun adalah Rp. $5,220,349,59$

Jika Perusahaan Daerah Air Minum (PDAM) Kota Blitar tidak berharap mendapatkan subsidi dari Pemerintah Daerah, dan untuk bias menutup seluruh beban usaha maka dapat menempuh kebijakan tariff baru untuk masing-masing kelompok pelanggan seperti pada table berikut ini.

Komposisi Konsumsi Air Minum Masyarakat Kota Blitar Per Kelompok Pelanggan, Kontribusi Beban Usaha, Rata-Rata Konsumsi Dan Tarif Seharusnya

\begin{tabular}{|c|c|c|c|c|}
\hline $\begin{array}{l}\text { Kelompok } \\
\text { Pelanggan }\end{array}$ & $\begin{array}{l}\% \\
\text { Konsums } \\
\text { i }\end{array}$ & $\begin{array}{l}\text { Beban } \\
\text { Usaha }\end{array}$ & $\begin{array}{l}\text { Rata-Rata } \\
\text { Konsumsi } \\
\left(\mathrm{m}^{3}\right)\end{array}$ & $\begin{array}{l}\text { Tarif } \\
\text { Seharusny } \\
\text { a }\end{array}$ \\
\hline Non Niaga & 88 & $\begin{array}{l}4,614,171,26 \\
9\end{array}$ & 792,330 & 5,824 \\
\hline Niaga & 3 & $155,425,103$ & 26,079 & 5,960 \\
\hline Sosial & 3 & $137,473,774$ & 22,858 & 6,014 \\
\hline $\begin{array}{l}\text { InstansiPemerint } \\
\text { ah }\end{array}$ & 4 & $228,075,681$ & 38,871 & 5,867 \\
\hline HanKam & 1 & $52,203,496$ & 9,744 & 5,358 \\
\hline KranUmum & 1 & $32,958,547$ & 5,205 & 6,332 \\
\hline
\end{tabular}

\section{KESIMPULAN DAN SARAN \\ Kesimpulan}

Dari hasil analisa yang telah dilakukan, kesimpulan yang dapat diberikan :

1. $B E P$ (unit) per tahun $=1,982,367 \mathrm{~m}^{3}$

2. $B E P(R p)$ per tahun= Rp.5,819,992,173.97,-

3. Sumber eksternal, subsidi Pemerintah Kota Blitar dan atau Pemerintah Provinsi Jawa Timur yang seharusnya diberikan agar bisa menutup seluruh beban usaha demi kelangsungan pelayanan Air Bersih kepada masyarakat Kota Blitar adalah sebesar Rp. $3,175,025,522$

4. Jika Perusahaan Daerah Air Minum (PDAM) Kota Blitar tidak berharap mendapatkan subsidi dari Pemerintah Daerah, dan untuk bisa menutup seluruh beban usaha maka dapat menempuh kebijakan tariff baru untuk masing-masing kelompok pelanggan per $\mathrm{m}^{3}$ Non Niaga Rp.5,824,- ; Niaga Rp.5,960,- ; Sosial Rp.6,014,- ; Instansi Pemerintah Rp.5,867,- ; Rp.5,358 dan Kran Umum Rp.6,332,-.

\section{Saran}

Sehubungan dengan tingginya tingkat BEP maka saran yang bisa diberikan dalam penelitian ini adalah melakukan penghematan 
besar-besaran, karena tidak mungkin akan mencari pelanggan yang dapat menghasilkan penjualan sebanyak 7.929.468 $\mathrm{m}^{3}$ 